\title{
Policy Document on Study Duration, Transfer Credits and Tutorial Classes in Higher Quality Accredited Institutions
}

\author{
Christo Ananth ${ }^{1}$ \\ ${ }^{1}$ College of Engineering, AMA International University, Kingdom of Bahrain
}

\begin{abstract}
This Policy Document characterize a base and most extreme examination term period for undergrad and graduate investigations. This strategy archive and techniques characterize the investigation term for various program levels and understudy classes in undergrad and graduate examinations just as in intelligent manner with the neighborhood standards and guidelines of Higher Education Body. This strategy covers the examination span for the undergrad and graduate projects, which are lined up with the Higher Education Body principles and guidelines. This Policy Document acknowledges students from other schools and credit courses dependent on the Transfer Credit Matrix of the University. The student from another school is required to finish in any event half of the required credit units/hours of a program. The most extreme credit units/hours that are qualified for exchange credits ought not surpass (66\%) of the required credit units/hours from the first level of another college. The Practicum/On-the-Job Training and Thesis/Capstone courses are not qualified for credit move. The student from another school must take these courses during his/her residency at University. The reason for the strategy record and technique is to control the senior members and the understudies in the prerequisite and procedure of crediting courses taken from different colleges. This strategy report and method spread the acknowledgment of moving understudy to be conceded credits towards the program, criteria and necessities connected for credit move, required number of credit units/hours and equality, and the evaluation required. This Policy Document likewise gives scholarly help to the scholastically in danger understudies by directing instructional exercise classes. This arrangement record and technique plans to guarantee that the scholastically in danger understudies are given the important help and direction to be capable adapt to the necessities of the course and the program. This strategy archive and method spread any authoritatively enlisted understudies of the University that need scholarly direction as suggested by the Academic Adviser, and any understudy who is scholastically in danger during the present term of enlistment. It displays the duty of the employees in giving scholastic help to the understudies, when vital.
\end{abstract}

Keywords - Higher Quality Accredited Institutions, Program Development, Program Review, Program Industry Advisory Panel, Program Intended Learning Outcomes.

\section{INTRODUCTION}

Leave of Absence- a period in understudy's examination where he/she was not taking any course in the college. Most extreme Length of Study-Equivalent to eight (8) years limit of study term (for undergrad) and six (6) years limit of study span (for alumni) Graduate Student-an alumni understudy who is at present enrolled between 6-12 units. Ordinary Length of the Study-Length of the program the understudy is taking, identical to the years characterized as a thought Undergraduate Student - A Bachelor Degree understudy who at present enlisted between 12 to 19 credits. Senior member guarantees exacting usage of the examination term arrangements and systems. Personnel Adviser-confirms and affirms the heaps understudies are selecting dependent on the understudy's educational program plan and current scholarly status. Division Head-screens the length and term of the understudy's stay in the college. Enlistment screens understudy's advancement and illuminates the understudies the investigation length took into consideration him/her to complete the program. Transferee - is an understudy who previously entered school and might want to look for admission to the University and applies for credit move of courses taken from other college. Move credit credits of courses taken from the first level of another college are moved towards the program 
Christo Ananth et al., International Journal of Advanced Research in Innovative Discoveries in Engineering and Applications[IJARIDEA]

Vol.3, Issue 4, 27 Auagust 2018, pg. 15-18

of the tolerant college. Instructional exercise classes will be classes led outside of normal hours to be offered to understudies having a characteristic of under half in the occasional evaluation. The employees are straightforwardly in charge of the instructional exercise classes of their understudies. The Academic Adviser makes the referral in the event that his advisees need scholarly direction. The Dean, Associate Deans, Department Heads guarantee that instructional exercise classes are done in like manner through instructional exercise classes' participation and refusal structures. Notwithstanding the instructional exercise classes as distinguished by the employees, the Guidance office, in a joint effort with the Dean's office plan and prescribe instructional exercise classes so as to take care of the understudies having general troubles. The conveyance of the instructional exercise classes all things considered is as yet guaranteed by employees where the observing and the understudy movement must be constrained by the direction office.

\section{PROCEDURES FOR STUDY DURATION}

Full-time students at the undergrad program have an ordinary term between 3.33 to 4 years without time away. The most extreme term can be stretched out to eight years, with a time away in the middle. On the off chance that the understudy records a time away, the leave of nonattendances is included in eight (8) years. Graduate understudies at the alumni program have a typical length of 2 years. The most extreme span can be reached out to six years, with a waiver of time away, in the middle. Most extreme residency standard is material to Undergraduate including time away 8 years according to Higher Education Body. Graduates including all endorsed time away is 6 years. Negligible residency rule for Undergraduate is Three years to four years. The student from another school is required to finish in any event half of the required credit units/hours of a program. For Graduate, it is Two years. Neglecting to follow the Maximum/Minimum residency standards will prompt no graduation. Quality Records incorporate Leave of Absence Form and Evaluation Form. These Documents are circulated to Overall Academic Dean, Registration Office, IT Department, Admissions Office, Colleges, Head of Quality Assurance and Accreditation Office

\section{PROCEDURES FOR CREDIT TRANSFER}

The course description is in any event $90 \%$ proportionate. The course substance and course learning results are in any event $90 \%$ comparable. The course credit unit/hour must be equivalent or more than the required course credit unit/hour of the course. Just identical course with an evaluation of at any rate " $\mathrm{C}$ " and higher will be considered for credit move. On the off chance that over $66 \%$ of the courses fulfill the evaluation necessities, the Dean has the privilege to browse the courses which will be granted with credit move. The evaluating arrangement of the previous college will be joined. Courses credited from the past college will be thought about the transcript of records of the understudies. Move credits is checked towards the consummation of the degree prerequisites yet are excluded in the calculation of the CGPA. Identical General Education/Minor courses taken from different colleges might be credited given that any understudy who will bomb the approval test for English and additionally Math must enlist the equivalent at University. He/she won't be required to select and take the MEP/PREN and/or Remedial Math if there are English and Math subjects that can be given credits. The evaluation in the real course connected for credit is 2.75 (C) or better. A transferee/shifter verifies move of credit structure from Admissions Office and rundown down courses which are qualified for credits Submits the structure together with a duplicate of transcript of records and course portrayals to Admissions Office for preparing. Affirmation Office presents the structure to the College Dean for evaluation and endorsement of credits. The College Dean assesses and supports the courses connected for exchange and 
Christo Ananth et al., International Journal of Advanced Research in Innovative Discoveries in Engineering and Applications[IJARIDEA]

Vol.3, Issue 4, 27 Auagust 2018, pg. 15-18

returns the structure to Admissions Office. The Admissions Office tells the understudy and requests that the understudy agree the credit that has been affirmed for exchange. The affirmed credit move is sent by the Admissions Office to the Registration Office for encoding. The Registration Office encodes the endorsed credits to the CIS. Quality Records incorporate Credit Transfer Form, Course Descriptions and Copy of Transcript of Records. These archives are disseminated to Registration Office, Admissions Office and Students.

\section{PROCEDURES FOR TUTORIAL CLASSES}

The College Dean conducts staff meeting toward the beginning of the term and talks about the employees' instructional exercise work in the event that they have scholastically in danger understudies. The College Dean guarantees that all employees recognize the rundown of required instructional exercise classes after each significant test. Instructional exercise classes are offered to understudies having a sign of under half in the occasional evaluation. The employees lead instructional exercise classes during their discussion hours. Understudies distinguished as in danger and requiring instructional exercise classes may decide to not go to the instructional exercise classes. In such case the concerned understudies should sign a particular waiver. The employees arrange with the understudies' guides to screen the effectiveness of the instructional exercise classes by intently estimating the understudy movement. In the event of instructional exercise classes prescribed by the direction office, employees should send an understudy participation report just as understudy grades movement to the direction office, which will solidify the information and produce the suitable observing and assessment reports. The Dean's office keeps quality records of the direct of instructional exercise classes of their individual educators. Quality Records incorporate Tutorial Classes Reports. This Document is circulated to Overall Academic Dean, College officials, Faculty individuals, Head of Overall Student Affairs, Head of Guidance and Head of Quality Assurance and Accreditation

\section{V. . CONCLUSION}

This Policy Document characterize a base and most extreme examination term period for undergrad and graduate investigations. This strategy archive and techniques characterize the investigation term for various program levels and understudy classes in undergrad and graduate examinations just as in intelligent manner with the neighborhood standards and guidelines of Higher Education Body. This strategy covers the examination span for the undergrad and graduate projects, which are lined up with the Higher Education Body principles and guidelines. This Policy Document acknowledges students from other schools and credit courses dependent on the Transfer Credit Matrix of the University. The student from another school is required to finish in any event half of the required credit units/hours of a program. The most extreme credit units/hours that are qualified for exchange credits ought not surpass $(66 \%)$ of the required credit units/hours from the first level of another college. The Practicum/On-the-Job Training and Thesis/Capstone courses are not qualified for credit move. The student from another school must take these courses during his/her residency at University. The reason for the strategy record and technique is to control the senior members and the understudies in the prerequisite and procedure of crediting courses taken from different colleges. This strategy report and method spread the acknowledgment of moving understudy to be conceded credits towards the program, criteria and necessities connected for credit move, required number of credit units/hours and equality, and the evaluation required. This Policy Document likewise gives scholarly help to the scholastically in danger understudies by directing instructional exercise classes. This arrangement record and technique plans to guarantee that the scholastically in danger understudies are given the 
Christo Ananth et al., International Journal of Advanced Research in Innovative Discoveries in Engineering and Applications[IJARIDEA]

Vol.3, Issue 4, 27 Auagust 2018, pg. 15-18

important help and direction to be capable adapt to the necessities of the course and the program. This strategy archive and method spread any authoritatively enlisted understudies of the University that need scholarly direction as suggested by the Academic Adviser, and any understudy who is scholastically in danger during the present term of enlistment. It displays the duty of the employees in giving scholastic help to the understudies, when vital.

\section{REFERENCES}

[1] Allport, G.A. (1955). Becoming. New Haven : Yale University Press.

[2] Clarke, P. (2001). Teaching and Learning : The Culture of Pedagogy. New Delhi/ Thousand Oaks/London : Sage Publications.

[3] DeRoche, E. F. and Williams, M. M. (1998). Educating Hearts and Minds. California: Corusin Press.

[4] Long, N. J., Morse, W.C., Fecser, F. A. and Newman, R. G. (2007). Conflict in the Classroom. Austin, Texas : 8700 Shoal Creek Boulevard.

[5] Leicester, M., Modgil, C. and Modgil S. (2000). Classroom Issues : Practice, Pedagogy and Curriculum (Vol.III). London: Falmer Press, 11 New Fetter Lane.

[6] National Council of Educational Research and Training (2005). National Curriculum Framework. New Delhi : NCERT.

[7] Pant, D. and Gulati, S. (2010). Ways to Peace : A Resource Book for Teachers. New Delhi : NCERT.

[8] Sharma, R. (2010). Schools in the Changing Times : Framework for Innovations in Schools beyond Studies. The International Journal of Learning, 16 (12), 321-326.

[9] UNESCO-APNIEVE (2002). Learning to Be (A Unesco APNIEVE Source Book No.2). Bangkok, Thailand : Asia and Pacific Bureau for Education 